\title{
Integrated refurbishment planning for sustainable office buildings
}

Thiemo Ebbert Dr Ing

Façade Planner, Imagine Envelope Façade Consulting, Bochum, Germany and Delft University of Technology, Faculty of Architecture, Chair Design of Construction, Delft, The Netherlands

Europe's cities are full of office buildings which are technically and visually outdated. Research has demonstrated that more than $60 \%$ of German office stock is in acute need for refurbishment. Building planning needs intelligent approaches to façade refurbishment in order to tackle this enormous market. This article presents the head office building of Sparkasse Vorderpfalz in Ludwigshafen, Germany as a typical example of 1970s architecture with corresponding refurbishment tasks. It has been refurbished by following an integral planning approach. Façade technology and building services installations have been treated as co-dependent features looking for the best synergetic effects. The entire refurbishment took place while the building was in use: 'Please do not stain the carpet!' was the motto stated by the client. With this approach, the Sparkasse Vorderpfalz Building has won the 2010 'ReSkinning Award' in the category 'large commercial'. The refurbished building has not only proven to be economically feasible, but its ecological and social sustainability has also been evaluated by Delft University of Technology. The experiences have the potential to inspire many more buildings to be refurbished and upvalued.

\section{Introduction}

Two-thirds of the office-stock in Western Europe is older than 30 years (Hoffmann, 2006). At this age façades and technical installations reach the end of their technical life-span and buildings show a bad performance in terms of user comfort and energy consumption. This situation leads to a high demand for refurbishment of office buildings constructed between 1950 and 1980. In Europe's five biggest economies (France, Germany, Italy, UK, Spain) this demand adds up to approximately 1 billion $\mathrm{m}^{2}$ GFA (Ebbert, 2010). Around $75 \%$ of end energy consumed in buildings of the tertiary sector is used for heating and cooling (Schlomann et al., 2004). Improvements in this aspect can thus lead to big savings both on financial as on ecologic level.

This paper illustrates an unconventional approach. Unlike most office refurbishments, during which the building is stripped to the load-bearing structure and rebuilt, this project was entirely refurbisheshed while being occupied. All interior finishings had previously been upgraded during a necessary asbestos removal. In this project the task was to renew building services and improve the insulation capacity of the building envelope in order to improve indoor comfort, energy performance and achitectural appearance.

\section{Building characteristics}

The building was constructed in 1974 and is composed of a three-storey base, which houses a conference centre of $3500 \mathrm{~m}_{\mathrm{GFA}}^{2}$, and a nine-storey office-tower on top of this base of $4500 \mathrm{~m}_{\text {GFA }}^{2}$. The base of the building is constructed in in situ concrete. The supporting structure of the office tower is formed by steel columns and beams. The floors are made of in situ concrete. Only four structural columns carry all vertical loads. The horizontal stiffening is achieved by the staircase and elevator shaft (Figure 1).

The building provides three different façade structures: The 'office façade', the so-called 'wings' in the four corners of the tower, and the 'base'. The 'office façade' of the tower used to be a combination of a curtain wall and ventilated cladding in one structure (Figure 2). It was supported by a framework of steel profiles, placed as a curtain wall in front of the floor edge and concrete parapet. This framework was filled using pressure plates known from stick-systems. The window units were equipped with insulated glass and provided the thermal layer. In front of the massive parapets, however, the façade was only clad with a noninsulated aluminium panel, which was ventilated in order to let air into the ventilation unit. Thus, outside air could reach the space above the suspended ceiling. To the outside of the spaceenclosing façade there used to be service platforms, carried by steel consoles cantilevering from the façade steel framework. These platforms served for window cleaning and carried Venetian blinds.

The closed corner-zones of the tower façade that are not equipped with windows (the so-called 'wings') were clad in a similar fashion to the parapets. Anodised aluminium panels were fixed to a steel framework. The walls behind were made of porous concrete blocks without further insulation. The original façade of the 'base' consisted of floor-high aluminium window units, which were equipped with insulated glass but did not provide thermal 


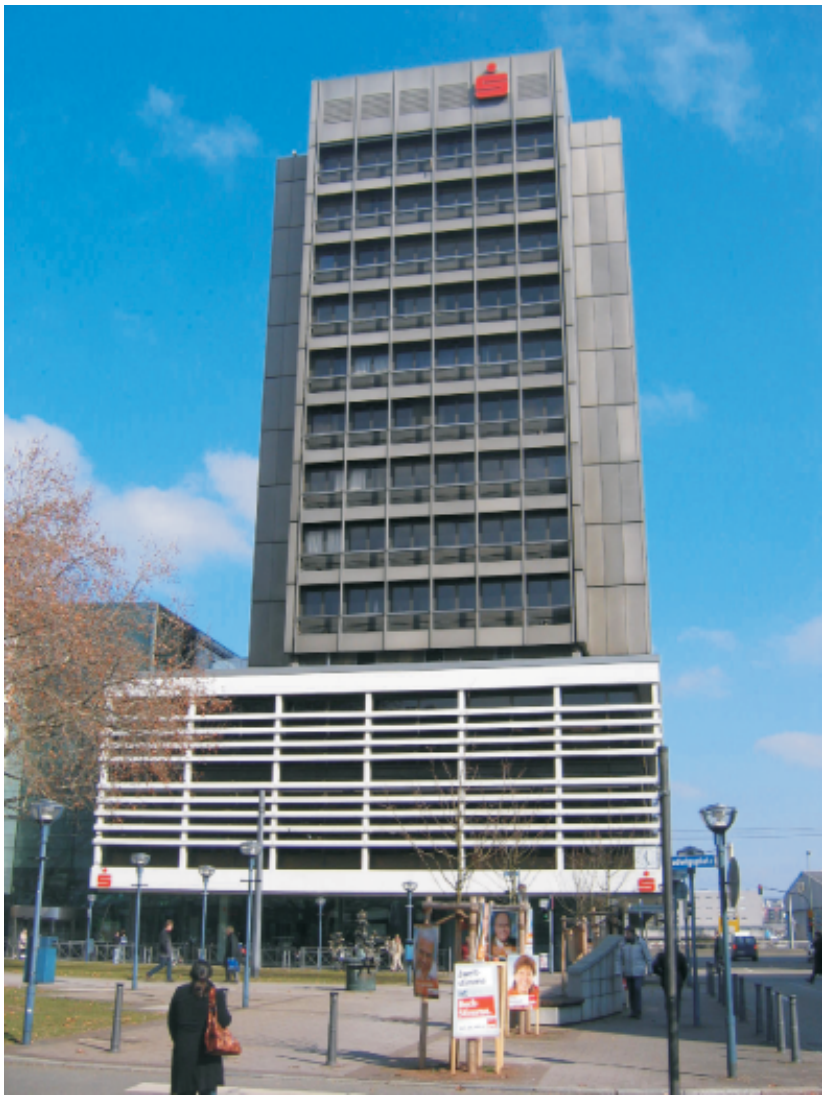

Figure 1. Sparkasse Vorderpfalz, impression before refurbishment

separation of the profiles. Exterior concrete louvres in front of the façade served for solar protection and decoration.

All office-spaces used to be fully air-conditioned by means of decentralised units. Fresh air was taken in directly through the façade. It was heated or chilled by HVAC units in the parapet cladding. Used air was let out through the same unit without recovering heat energy. The system was controlled centrally and not adjustable by the user.

\section{Refurbishment tasks}

The entire façade and building services were technically outdated. Major constructional problems of the façade consisted of rainwater entering the construction along the service platforms, as well as in very poor thermal insulation and wind-tightness. The building consumed over $290 \mathrm{kWh} / \mathrm{m}^{2}$ year of final energy, of which approximately $80 \%$ was used for heating and cooling. All physical aspects of the building and the HVAC installations had to be brought up to current standards, fulfillng the German Energy Saving Directive for new constructions (EnEV, 2007) in order to reduce operational costs and energy consumption significantly.
The users asked for more influence on their personal indoor climate and improved daylight quality, particularly in the conference area. The client also desired to modernise the building's appearance. It should be given a more open and communicative design. Special consideration was needed for the fact that the interior had recently been refurbished and the building was to be kept in operation.

\section{Refurbishment solution}

Based on the given circumstances three different designs were developed (Figure 3). These have been evaluated by thermodynamic simulation with the software 'DK-integral' by Delzer Kybernetik, which generates hourly airflows and temperature performance, and delivers the necessary energy to achieve a comfortabel indoor climate (Delzer, 2011). Based on these results, the life-cycle costs for each option have been estimated, which provided the basis for decision making (Ebbert, 2010).

In a 'necessary restoration solution' (version 1) existing windows and climate-units were replaced and extra insulation added. In the feasibility study this led to extra costs for relocation of staff and renovation of the interior while the maximum positive effect on energy saving could not be reached in simulations. A second option aimed on maximising the energy savings and passive energy gains (version 3). In this design a climate skin was installed; solar-chimneys contributed to the support of natural ventilation. This solution proved to be too expensive in comparison with the achievable payback on energy saving and added property value.

The preferred solution (version 2) is characterised by an integral planning of façade and climate installations. The new façade takes advantage of the existing service platforms. It places an additional façade layer on their outer edge. Vertical profiles, suspended from steel girders, carry all vertical loads. Horizontal loads are brought directly into the existing consoles. Additional steel beams that are necessary to transfer the loads of the new façade to the existing structure were installed on the roof. Inside the building only four diagonal beams had to be added to improve the original structur (Figure 4). A new cleaning cradle had to be installed on the roof. During construction time, this cradle was used as a crane to mount the outer glass panes, which have a dimension of $3.50 \mathrm{~m} \times 2.40 \mathrm{~m}$.

After the outer façade was closed, the interior façade could be renovated independently of the weather. The sub-structure of the original façade stayed in place. Only the filling elements have been replaced by new windows and insulated panels (Figure 5). New climate units are installed inside the cavity. Thus, the refurbishment took place without interfering with the interior of the office. In the end, it took only eight days of work inside to refurbish one entire floor, including the relocation of staff and cleaning.

For the refurbishment of the outer corners of the tower a very 


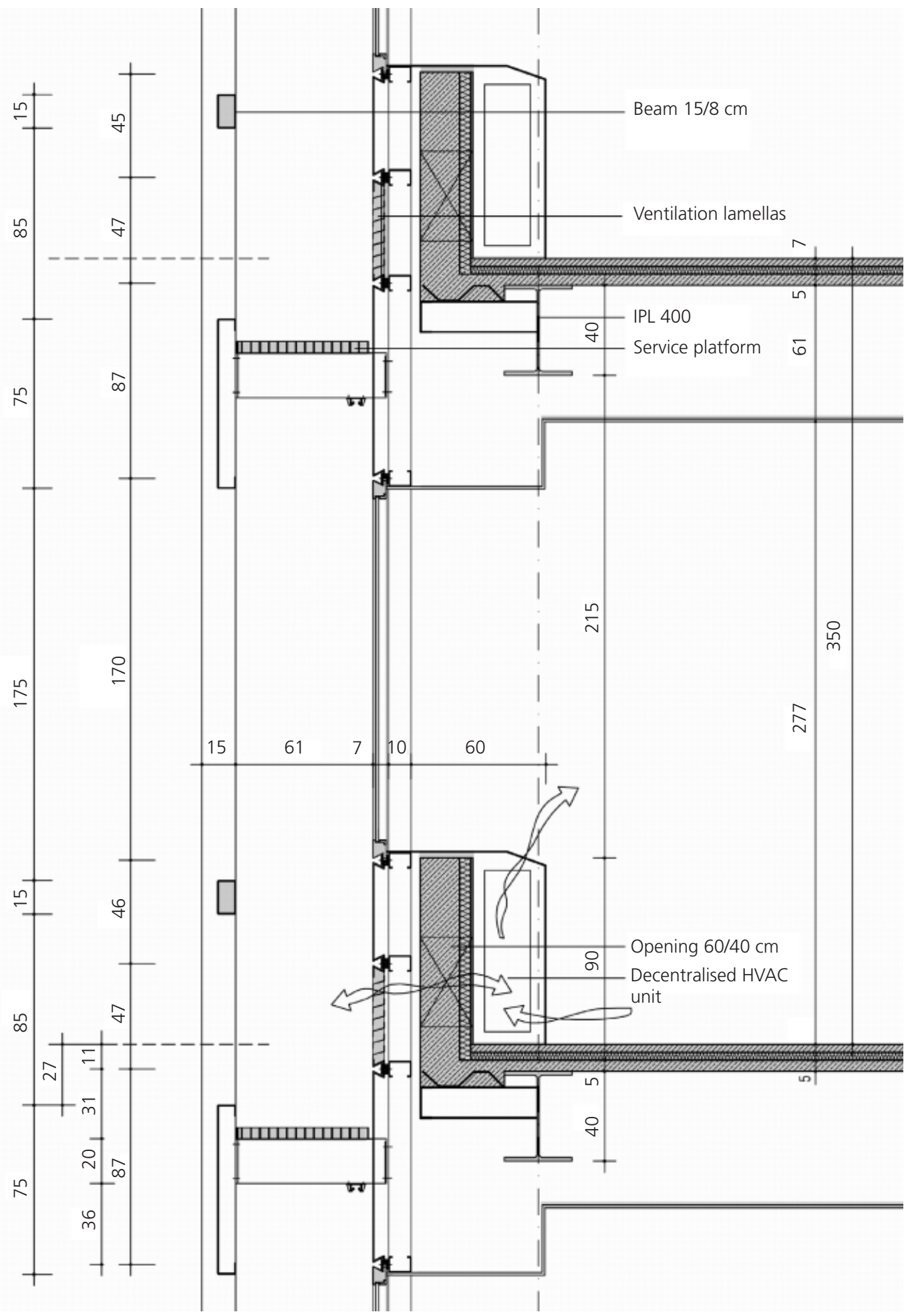

Figure 2. Cross-section of initial office façade

simple and effective solution could be found (Figure 6). The original aluminium panels with a thickness of $4 \mathrm{~mm}$ proved to be of a very high quality. The sub-structure initially provided a ventilated cavity of $150 \mathrm{~mm}$. These facts made it possible to reuse most of the façade cladding. The cavity was insulated with $100 \mathrm{~mm}$ of mineral wool. The aluminium panels were cleaned, anodised to prevent filiform corrosion, newly coated, and remounted onto the existing structure using the old pressure plates 

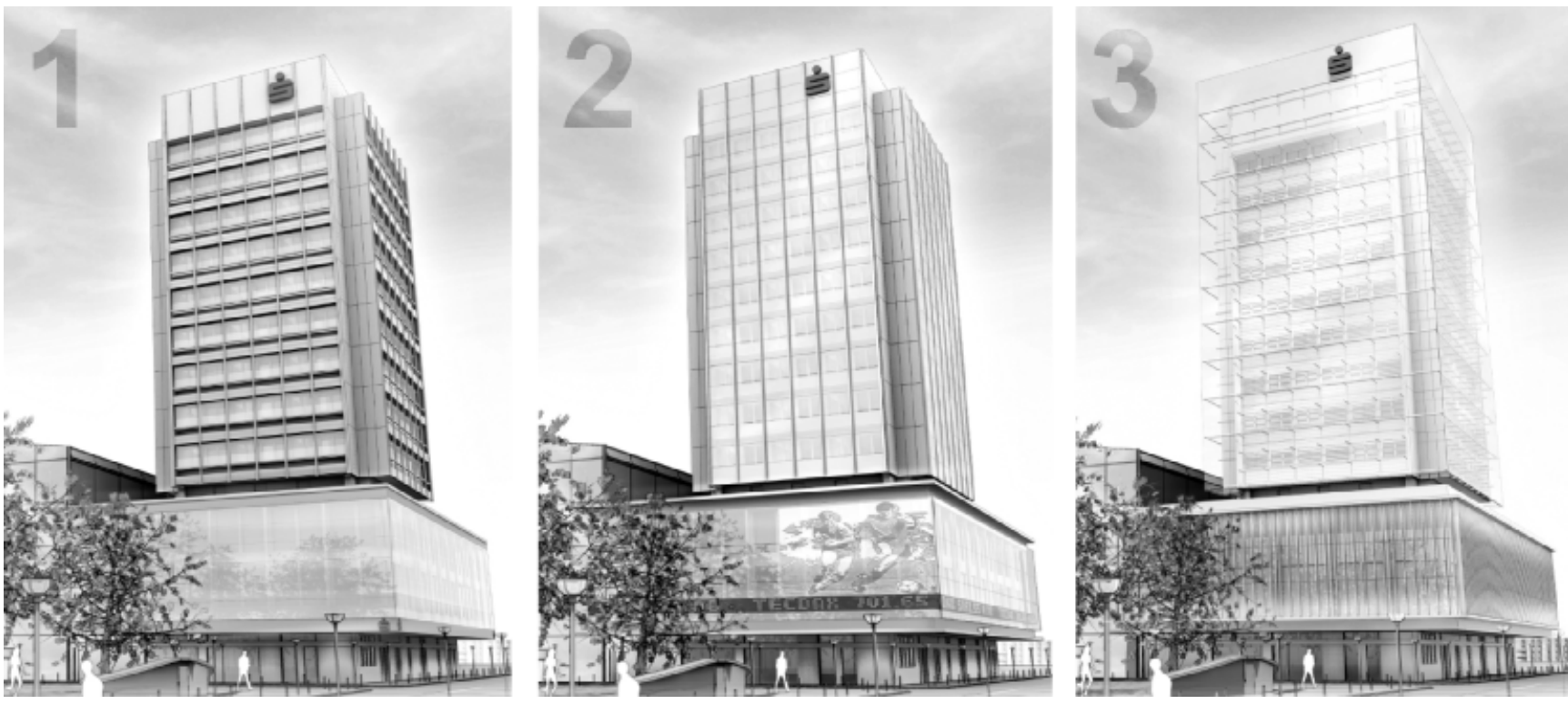

Figure 3. Renderings of the three compared refurbishment concepts

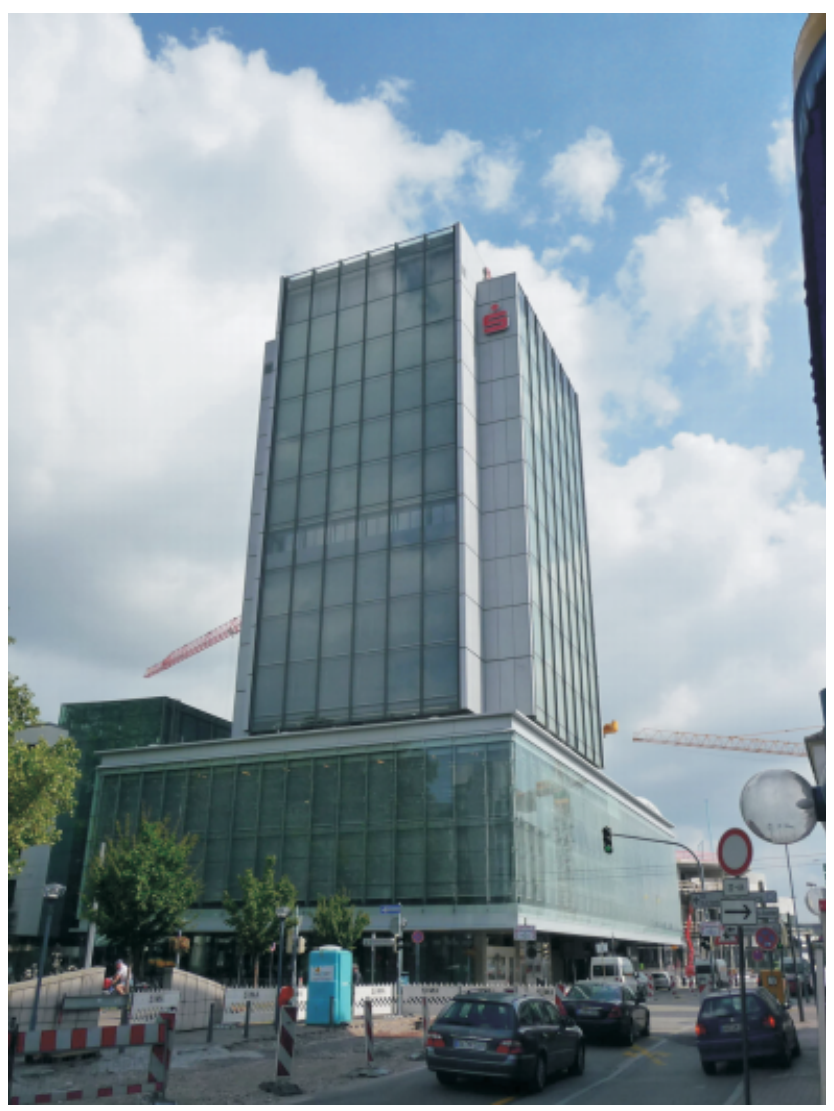

Figure 4. Sparkasse Vorderpfalz, elevation after refurbishment and new gaskets. Thus, more than $80 \%$ (approximately $900 \mathrm{~m}^{2}$ ) of the old façade could be preserved.

The conference space in the base zone of the building also demanded a refurbishment concept that could be realised from the exterior. Here a second façade layer has been installed, which prevents the weather impact on the original primary façade. Rainwater tightness and drainage do not need to be considered any more; the façade mainly has to provide the necessary thermal insulation and vapour tightness. This is achieved by replacing the glass and mounting insulated cover profiles on top of the outside of the original window profiles. In combination with the double façade this solution achieves sufficient thermal insulation, effectively prevents condensation, and permits a refurbishment without disturbance of interior finishings.

\section{Climate concept}

All office spaces are fully air-conditioned by means of decentralised units. Initially, fresh air was taken in directly through the façade, heated or cooled by an HVAC unit inside the interior parapet cladding and brought into the room. Exhaust air was then let out through the same unit without recovering heat energy. After refurbishment, the climate concept takes advantage of the new double façade to improve the energy performance. It uses the cavity space to place new de-centralised climate units. These units measure $120 \mathrm{~cm} \times 90 \mathrm{~cm} \times 22 \mathrm{~cm}$ and house two fans, a cross-flow-heat recovery with an effectivity of $65 \%$ (Evers, Balck und Partner TU Delft, 2006), filters, electronic controls, and the 


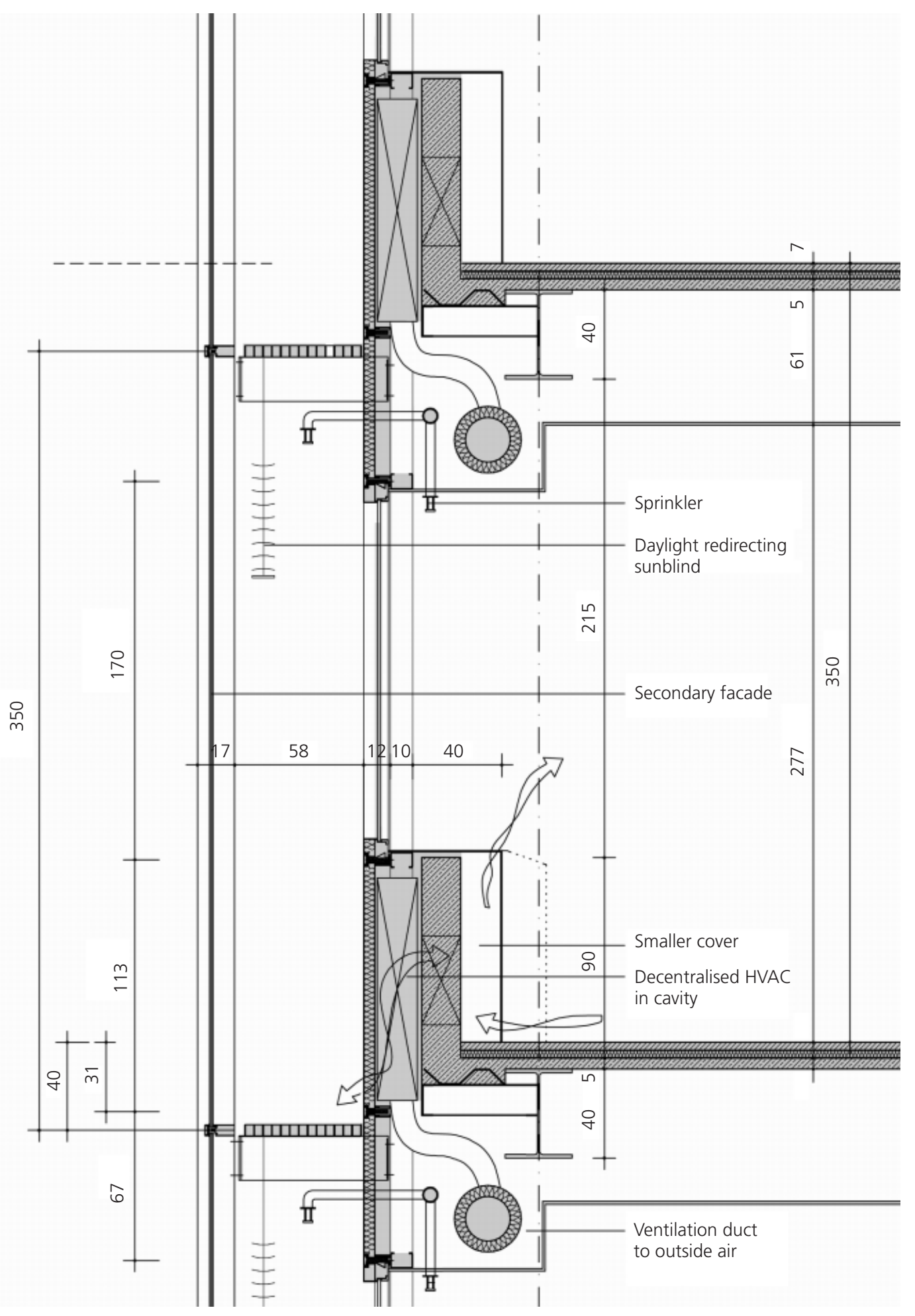

Figure 5. Cross-section of the façade after refurbishment

necessary wings to draw air in from two different zones and blow it into the room in two different directions (Figure 7).

In winter, fresh air is let in at the bottom of the façade cavity and preconditioned by solar irradiation. Additionally, the air can be transported from the east to the west cavity in the morning and vice versa in the afternoon in order to optimise the air temperatures in both cavities. The climate units then take in the air from 


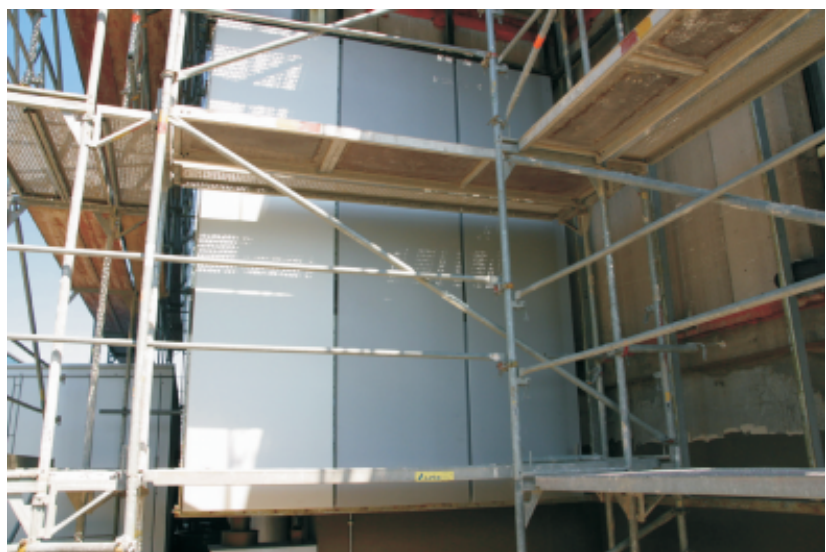

Figure 6. Mock-up of original façade panels with different new coatings: test of colour, reflectivity and weather resistance

the cavity. Exhaust air is let out through a duct directly connected to the outside.

In summer the system is reversed. Fresh air is drawn in from outside. The cavity is opened on the top and closed on the bottom. The solar irradiation creates a stack effect in the cavity, which extracts the air from the rooms. Thus, less electric energy is needed to run the mechanical fans in the climate units.

This decentralised system provides many advantages. It eliminates the need for air transport in the building. Fresh air is brought in and conditioned only when and directly where it is needed. Heating and cooling is controlled separately for each room. Using water as means of heat transport is far more efficient than air, as its heat capacity is 3300 times higher. It only demands relatively small circulation pumps and there are no huge ducts needed.

Next to the high efficiency this installation also provides the optimal individual comfort. A bus-system of sensors and actuators monitors and manages the entire building services. It is set to prevent excessive heat gains centrally, but also to value the users' wishes on individual comfort. Each office room is equipped with a user interface, which controls the desired temperature and electric. The very fast HVAC system reacts rapidly to these settings. Presence controllers in each room register if the room is in use. As soon as it is empty, ventilation and lighting are turned off. When the room is in use, $\mathrm{CO}_{2}$ sensors monitor the necessary ventilation rate. These sensors also function as fire-detectors, which eliminates the need for further installations.

Special concern has been taken for the sun-protection means. Innovative daylight deflecting Venetian blinds have been mounted inside the cavity (Figure 8). These blinds are shaped to block direct sunlight effectively even in an open position. Part of the

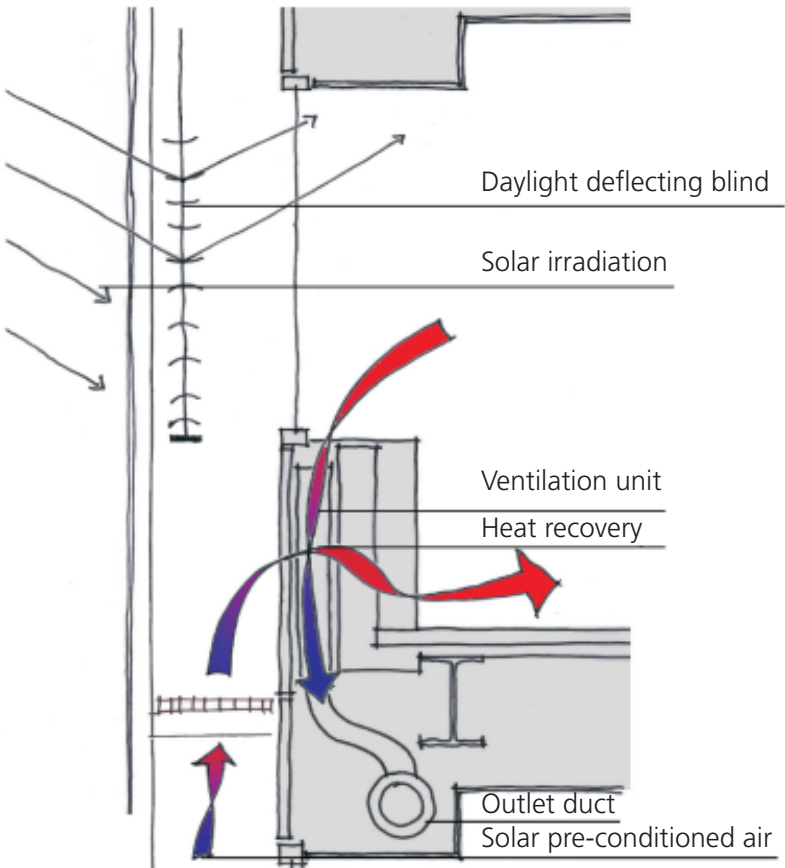

(a)

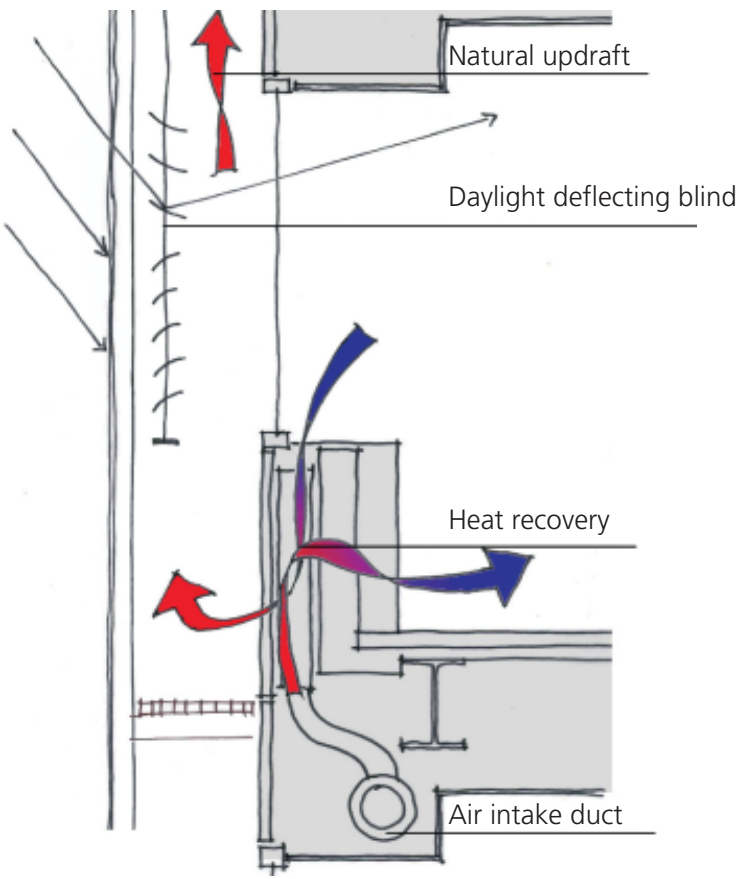

(b)

Figure 7. Ventilation schemes: (a) winter situation with façade serving as solar collector; (b) summer situation with cavity serving as solar chimney

light is deflected into the room and reflected again from the white ceiling. Thus, the need for electric lighting is reduced, energy demand and thermal loads are reduced, and the occupant has a good view outside at any time. 


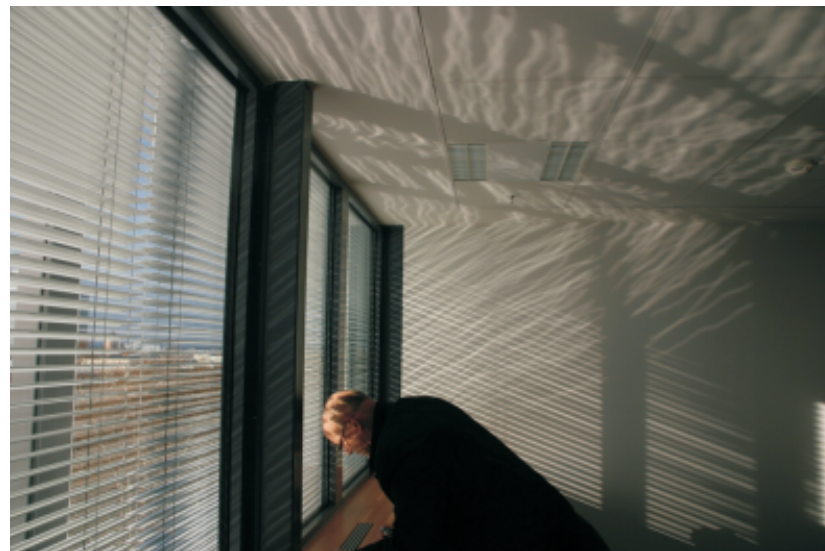

Figure 8. The Venetian blinds inside the cavity reflect daylight to the ceiling and thus deep into the room

\section{Sustainability in the original sense}

The project lives up the aims of ecological, economical, and social sustainability. The refurbished building has been certified as a 'green building' by the German Energy Agency (dena) according to the standards of the European Union.

In order to evaluate the future energy-saving potential, the original building and the refurbishment design have been tested by thermodynamic simulation. The initial situation delivered a demand of final energy for heating, cooling, service energy and electric lighting of $259 \mathrm{kWh} / \mathrm{m}^{2}$ year, which resembles a primary energy demand of $115 \mathrm{kWh} / \mathrm{m}^{2}$ year. It is interesting to see that the demand of primary energy is lower than that of final energy. This is owed to the energy sources. While cooling and electric lighting are powered by electricity with a primary energy factor of $2 \cdot 7$, the heating energy is provided by district heating, which is generated in a waste incineration plant in close proximity. Thus, the inner city area of Ludwigshafen is supplied with excess heat energy with a primary energy factor of $0 \cdot 2$. After refurbishment, the improvement to the thermal insulation of the façade, the intelligent HVAC concept, and the contribution of the daylightdeflecting sun blinds result in a reduction of energy demand of $64 \cdot 3 \%$. The building today demands $289 \mathrm{kWh} / \mathrm{m}^{2}$ of final energy and $115 \mathrm{kWh} / \mathrm{m}^{2}$ year of primary energy.

Furthermore, the refurbishment has significantly improved the comfort inside the building, which contributes to the satisfaction, health, and productivity of the occupants. The initial problems of drought and cold radiation have been eliminated. The office rooms provide much better day lighting and each user is enabled to individually influence the room temperature and lighting level.

Next to comfort and energy performance, the project has proven to be economically feasible too. The construction cost of the realised refurbishment totalled $650 € / \mathrm{m}^{2}$ for the refurbished façade and $250 € / \mathrm{m}^{2}$ GFA for the renewed building services. The double façade consists of a relatively simple secondary façade that reduces the demands for the primary façade, which can hence be cheaper. Furthermore, the concept provided the major advantage, that the entire refurbishment could take place while the building was in operation. This eliminated the need for relocation of staff and additional rent for an interim location.

The improved insulation, the ventilation concept and the use of solar gains in the façade reduce the energy costs significantly. The new technical installations require much less maintenance. Using individual monitoring makes it possible to optimise service intervals for each unit. By placing the ventilation units in the cavities these are easier accessible than inside an office room. The total operational costs could be reduced by more than $50 \%$. Taking construction costs and operational costs in one calculation delivers the life-cycle costs in comparison with the initial situation. In this case, the investment pays back on energy savings and improved maintenance within 13 years (Figure 9).

This feasibility analysis has not taken into account any further added value, such as no loss of productivity, which usually goes along with relocations, or better lettability and higher rental rates, which can be achieved. One example shall illustrate further benefits: the new, smaller, air-conditioning units are placed in the façade cavity, which vacates the space of the original units inside the office. By removing the interior parapet cladding panels of those units, $14 \mathrm{~m}^{2}$ of usable area can be activated per floor, which equals an increase of rental space by $4 \%$.

\section{Conclusion}

In many aspects this project presents common tasks in office refurbishment, which also made it interesting for being part of the author's doctoral research Re-Face - Refurbishment Strategies for the Technical Improvement of Office Façades conducted at Delft University of Technology.

The building presents different façade types which have been very common in Europe in the 1960s, 1970s and 1980s. The

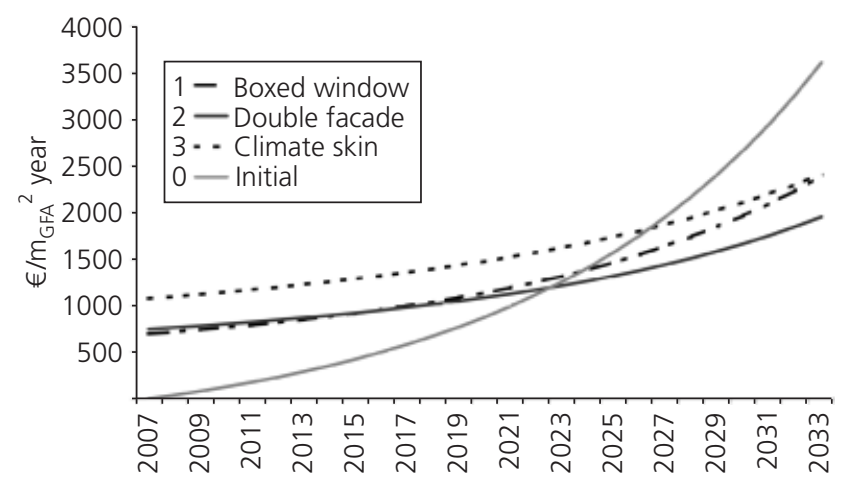

Figure 9. Life-cycle costing: the three refurbishment approaches are compared on construction and operational costs. The preferred option ' 2 ' pays back within 13 years of operation 
project also provides a combination of common tasks in construction, ventilation concept and the requirements for a construction process and logistics for an inner city location. Much care had to be taken for the users. The proposal thus had to be applied fast, safely, and with minimal nuisance. These demands apply to many buildings, which are to be renovated while remaining in use.

The application of a double façade is certainly not the solution of choice for any project. However, for those buildings that provide the structural and functional capacities, it can form a very costefficient solution. 'Wrapping up' the building creates a protected space in which the original façade can be improved independently from the weather but still outside the office room. The cavity provides the space to install new building service ducts and units. Thus, the interference with interior finishings and nuisance for the user are minimised - during the entire refurbishment the building can stay in use. Furthermore, such a solution improves building logistics for an inner city location. Only the necessary goods are transported on site. The new façade and building services can be applied fast and safely. The example of reusing cladding panels, by cleaning and recoating them, shows that it is possible to save a lot of material in construction, which scores high in sustainability ratings.

Furthermore, retrofitting office buildings provides social benefits. It helps to improve the urban surrounding, prevents the decay of inner city locations and reduces urban sprawl. The thorough dialogue with the original design leads to a development of a location towards the future without neglecting its heritage. Renovating a building which is in use has not only proven to be an economically feasible solution eliminating relocation expenses; it also gives the occupants the chance to identify with their work environment and enjoy the modernised work space without having to re-orientate entirely. With this retrofitting approach, this project has been awarded the Re-Skinning Award 2010 in the category 'large commercial' as best façade refurbishment. It serves as an inspiring example of how it is possible to create a modern, efficient, and comfortable workspace 'without staining the carpet'.

\section{Building characteristics}

Sparkasse Vorderpfalz, Hauptverwaltung, Ludwigshafen, Germany. Year of construction: 1974; architect: Egon Weiss; year of refurbishment: 2009.

Client: Sparkasse Vorderpfalz, Ludwigstraße 52, 67059

Ludwigshafen am Rhein, Germany (www.sparkassevorderpfalz.de)

Project management: Evers Ingenieurgesellschaft, Am

Lachengraben 7, D-63303 Dreieich, Germany (www.r-evers.com)

Façade planning: imagine envelope bv, Van Campenvaart 89,

2497 ZC The Hague, The Netherlands (www.imagine-

envelope.eu)

Climate engineering: Balck + Partner, Obere Neckarstraße 21,

D-69117 Heidelberg, Germany (www.balck-partner.de)
Structural engineering: KMS Ingenieure GmbH, Kirchweg 10, D-34121 Kassel, Germany (www.kms-ingenieure.de)

Academic support: Delft University of Technology, Faculty of Architecture, Chair Design of Construction, Julianalaan 132, NL-2611 KW Delft, The Netherlands (www.doc.bk.tudelft.nl) Doctoral dissertation: Re-Face - Refurbishment Strategies for the Technical Improvement of Office Façades, Dr.-Ing. Thiemo

Ebbert. ISBN: 978-90-8570-499-7 (www.th-e.de)

Award: Re-Skinning Award 2010 (www.thezeroprize.com)

\section{REFERENCES}

Delzer S (2011) http://www.dk-integral.de (assessed 01/04/2011).

Ebbert T (2010) Re-Face - Refurbishment Strategies for the

Technical Improvement of Office Façades. Delft University of Technology, Delft, the Netherlands.

EnEV (2007) http://www.gesetze-im-internet.de/enev_2007/ index.html (accessed 24/11/2007).

Evers, Balck und Partner TU Delft (2006) Feasibility Study. Sparkasse Ludwigshafen, Ludwigshafen, Germany.

Hoffmann C (2006) Was wissen wir über den Gebäudebestand an Nichtwohn- und Wohngebäuden in Deutschland und Europa?

- Eine Literaturrecherche. Gesundheitsingenieur -

Haustechnik - Bauphysik - Umwelttechnik 127: 69-75 (in German).

Schlomann B, Gruber E and Eichammer W (2004) Energieverbrauch der privaten Haushalte und des Sektors GHD. Technology Report No. 17/02, Fraunhofer Institut für Systentechnik und Innovationsforschung, Karlsruhe, Germany (in German).

\section{WHAT DO YOU THINK?}

To discuss this paper, please email up to 500 words to the editor at journals@ice.org.uk. Your contribution will be forwarded to the author(s) for a reply and, if considered appropriate by the editorial panel, will be published as a discussion in a future issue of the journal.

Proceedings journals rely entirely on contributions sent in by civil engineering professionals, academics and students. Papers should be 2000-5000 words long (briefing papers should be 1000-2000 words long), with adequate illustrations and references. You can submit your paper online via www.icevirtuallibrary.com/content/journals, where you will also find detailed author guidelines. 